\title{
電位差計に依万特殊鋼の分析法(其の九續き)
}

\section{タングステンの新容量分析法 (補遺)}

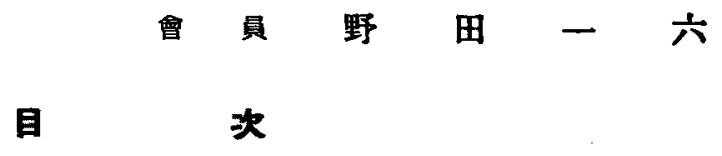

I. 緹言

II. 試料溶液

(1) $p \mathrm{H}$ 值こ洞定曲線

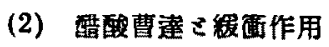

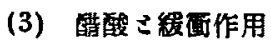

(4) 溫度さ缓橿作用
(5) 炭酰瓦斯三容液の安定度

III. 特珠銅に通用
(1) 提 作 法
(2) 各種の分析結果

IV. 結

㔄

\section{I. 緒 西}

前報に於てはタングステン酸を過剩のアル カリに溶解してタングステン酸アルカリと なしこつに過剩となつたアルカリは硝酸で 特別の注意の下に中和を行ひ試料溶液を調製 する旨報告した。けれども此の硝酸で中和し
安定なる溶液さ得る操作は特別の熟練を要す えと共にヌこの操作如何に依つては滴定の最 後の結果が決せらるつ程なれば更にこの點に つき本報に於て補足を行ひたり。

\section{II. 試料溶液と安定度}

菜沸させ乍ら硝酸で中和を行ひフェノール

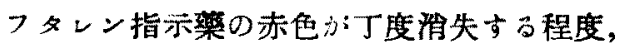
師与 $p H 8$ 前後に調節した溶液 $270^{\circ} \mathrm{C}$ 以上 ひ溫度で電位滴定行人ば大體良好なる滴足 經過告辿り而も明碓なる滴定終點都得らるう 事点知つた。即古少くの如く $70^{\circ} \mathrm{C}$ 以上に於 て滴定を行へば反應生成物たる硝酸曹橽に伐

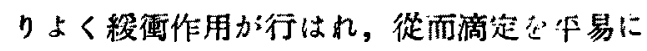
進行し得らるつ等なるに，向應滴定溶液の

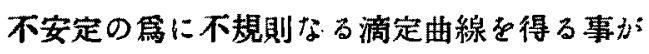
おつた。依つてこれへ改めて緩衙溶腹を加一
更に满定溶液の安定化を試みる事とせり。

\section{(1) pH 値上滴定曲線}

タングステン酸曹達溶液主・硝酸鉛溶液で滴 ・定士る際に起る酸恻:度の變化の模㥞尼更に詳 細に知る雼 $1 \%$ タングステン酸曹澾溶液 $5 \mathrm{cc}$ $200 \mathrm{cc}$ に稀粆したる中一 $\frac{N}{20}$ 硝酸鉛規定液 滴加し午， $p H$ 值の變化の模様を調べた. その結果岋第 1 圆に示す如く大部分の滴定操 作か; $p H$ 約 7.3 で進行し $\frac{N}{20}$ 硝酸鉛規定液の 約 $6 \mathrm{ce}$ 支扣入 $\tau p H$ 約 6.5 附近になつた時か ら反應の終點に近付く事を知る。 
第 1 闻

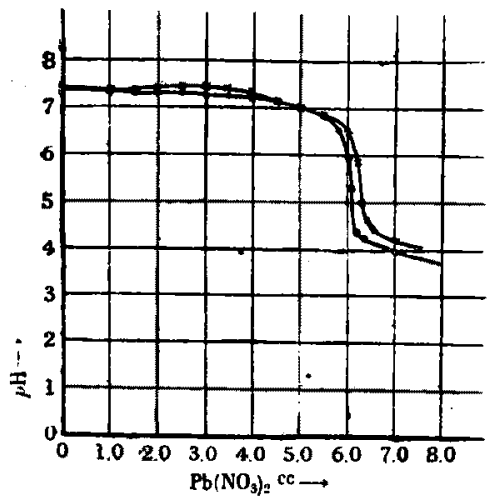

次には更に $19.00 \%$ タングステン含有 ナる高速度鋼 1 g 娄秤取し之より得らさつタ ングステン酸の沈澱を過剩のアルカリに溶解 して引續き硝酸で中和し得らうつ溶液の $\frac{1}{50}$ 容を分液して滴定行行ひたるに第 2 局の如き

第 2 闃

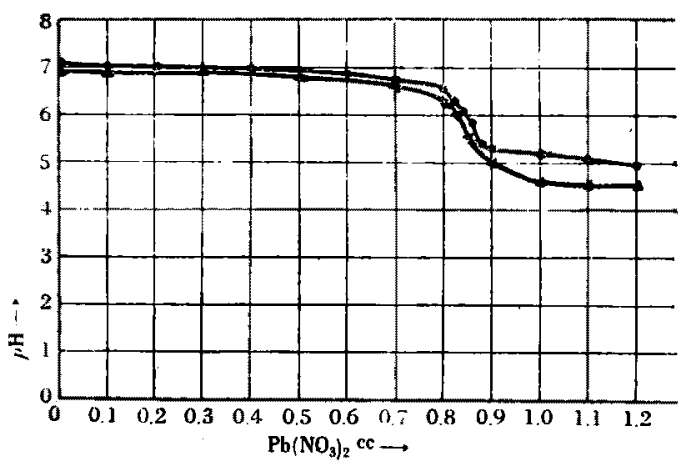

pH の戀化を表した。即ち前記純タングステ ン酸曹達溶液に於けると同様大部分の滴定操 作加凡飞 $p \mathrm{H} 7$ 前啳で進行し, $p \mathrm{H} 6.5$ 附近上 ク滴定終點に差しからる事を知つた，以上よ クこの滴定溶液に加へる綏衙溶液としては pH の 6.5 より大なる籁圍に於て紱衙作用を 表すもの尼用ひればよい事となる。

\section{（2）醋酸霉迋と綏衝作用}

$1 \%$ タングステン酸曹達溶液を $10 \mathrm{cc}$ 殖 7

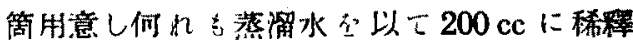
した: 只後 $5 \%$ 醋酸曹達溶被さ夫第 1 表の如 第 1 表

\begin{tabular}{|c|c|c|c|c|c|c|c|c|}
\hline 番 㟍 & (1) & (2) & (3) & (4) & (3) & (6) & (7) & (8) \\
\hline 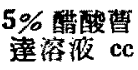 & 0.1 & 0.3 & 0.6 & 0.8 & 1.0 & 5.0 & 10. & 20 \\
\hline
\end{tabular}

く種々の分量加へて室溫で滴定したる結果は 第 3 图 (1), (2), (3), (4), (5), (6), (7), (8) 单線 の如く注れり，之等上り見るに $5 \%$ 醋酸曹详 溶液の約 $0.3 \mathrm{cc}$ 以下を加ふる時は宝溫で滴定 $し て ょ ょ$ 滴定溶液の安定が得られ，從つて 反應終點に近附く迄 $p \mathrm{H}$ の戀動を少く操作 し得られて, 而当明膫な反應終點が得られる

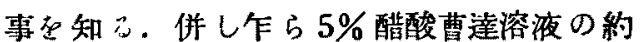
$0.6 \mathrm{cc}$ 以上学用ひける時は㖃衙作用は十分に

第 3 圖

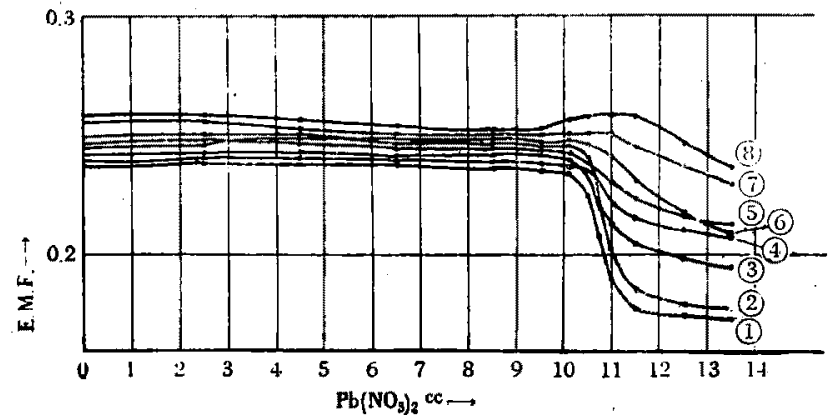




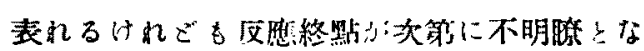
ク，極端なる㸟合として $20 \mathrm{cc}$ 前挠九加へた

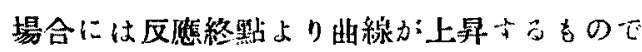
ある。之は一度生成したタングステン酸鉛か： 多量の醋酸曹洋と作用して次式の如く極めて

$\mathrm{PbWO}_{4}+2 \mathrm{NaC}_{2} \mathrm{H}_{3} \mathrm{O}_{2}=\mathrm{Na}_{2} \mathrm{WO}_{4}$

$$
+\mathrm{Pb}\left(\mathrm{C}_{2} \mathrm{H}_{3} \mathrm{O}_{2}\right)_{2}
$$

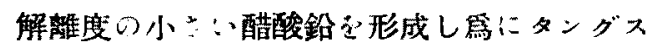
テン酸鉛より容易に醋酸鉛卆生する或とな

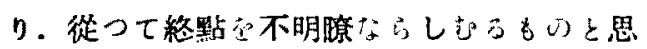
ふ. 又明線か縔點に於て上昇子るのは反應の 結果一部生よるタンがステン陵曹達少加水解 離する䉆に僅かにアルカリ性となるものと考 へらろ. 以上の現象より考人て或は醋酸のみ を緩衝溶液もして加いだ場合に注之か：如何に
なってあらうか，次にその研究卆行及事とし たり

\section{（3）醋酸と綵街作用}

醋酸のみを添扣しだ場合の嗳衝作用を調べ さ焉 $1 \%$ タングステン酸曹達溶液の $10 \mathrm{cc}$ 宛

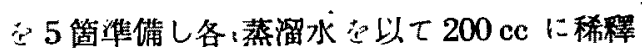
したるる後第 2 表の如く稀蔣醋酸（比重 1.005）

第 2 表

\begin{tabular}{|c|c|c|c|c|c|}
\hline 番啒 & (1) & (2) & (3) & (4) & () \\
\hline $\begin{array}{c}\text { 策櫒醋酸 } \\
\text { cc }\end{array}$ & 1.00 & 0.50 & 0.30 & 0.15 & 0.10 \\
\hline
\end{tabular}

の種々の量を添加して室溫て $\frac{N}{20}$ 硝酸鉛規定 液に依り滴定したる結果は第 4 圆 (1)，(2)，(3)， (4)，(5)曲線の如し、之等在見るに何れる滴定 開秮してから反應门終點に近付く迄酸性度

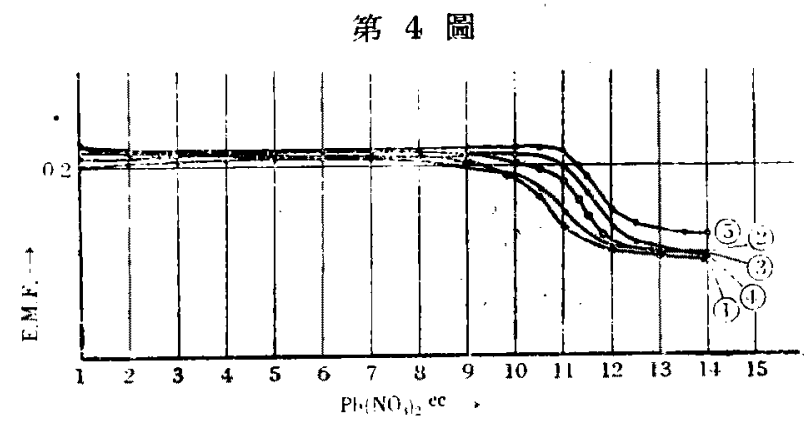

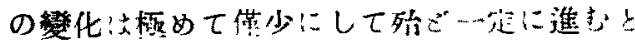
ち云ひ得られる。併し乍ら滴定終點に於ける

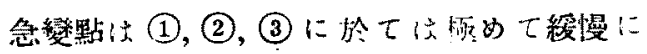

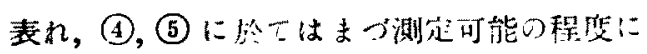

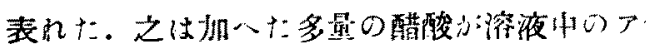

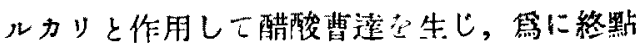
を不明暸ならしめたものと考人られる。從つ て前項沪於て述心た如き限量がこの醋酸の場 合にも自然存在する事を首肯出來ると思ふ。

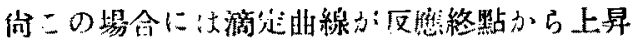

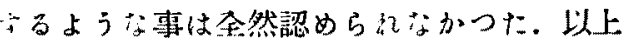
の結果より醋酸（比重 1.005）の添加量として

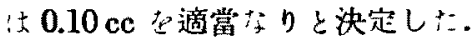

\section{（4）盢度と緩街作用}

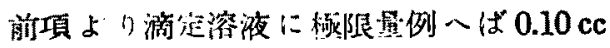

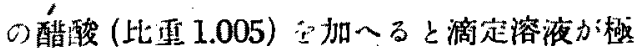
めて安定をなり矞に滴定操作か室溫で容易 に行ひ得らるつ樣になる事知つた。湖し乍 
ら滴定溶液の溫度を上昇させて反應地促進せ しゅ以て反應終點を明確ならしめんとする時 には果してこの緩衙作用が溫度の学に如何に

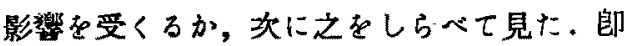
ち $1 \%$ タングスラン酸曹趃溶液の $10 \mathrm{cc}$ 宛 6
箅を用意し，夫々上記と同様に處理して之に 稀薄醋酸(此重 1.005)の約 $0.10 \mathrm{cc}$ 宛を添加し たる後 $25^{\circ}, 40^{\circ}, 55^{\circ}, 65^{\circ}, 75^{\circ}, 85^{\circ} \mathrm{C}$ の各 溫度に於て滴定したる結果は第 5 圖 (1)，(2)， (3)，(4)，(5)，(6) 眏線の如くなれり．之等上り

第 5 圆

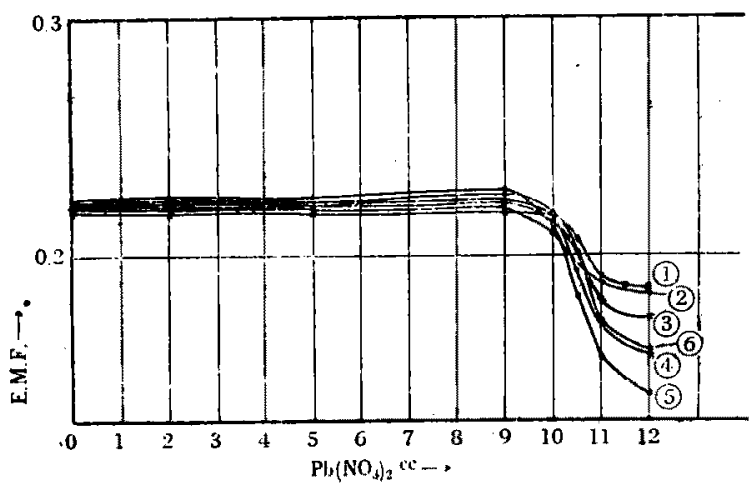

見らる〉やうに滴定溶液の温度か; $25^{\circ} \sim 85^{\circ} \mathrm{C}$ 位に變化してき綏衝作用には何等影響する所

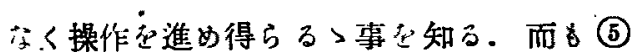
曲線の場合の $75^{\circ} \mathrm{C}$ 附近に於七は反應終點か； 最も顯著に表れるか故に滴定溫度としては $75^{\circ} \mathrm{C}$ 前後が一番好適なりと言ひ得らる。

（5）咴酸瓦斯之溶液の安定度

滴定溶液中のアルルリから炭酸か駩逐さ

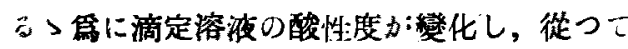
電位に動播导生する事は既に前報に於てる言 及しておいたがその間の樣子を更に詳しく究 める事とした，即ち $1 \%$ タングステン酸曹澾 溶液の $10 \mathrm{cc}$ 宛をとり蒸溜水で $200 \mathrm{cc}$ に稀程 したる後之を十分に煮沸して炭酸瓦斯を遂出 し直らに室溫に泠却してから㩨拌し乍ら電位

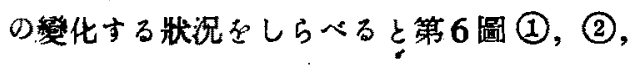
(3)の如くになる．即ち電位は刻々に變化し

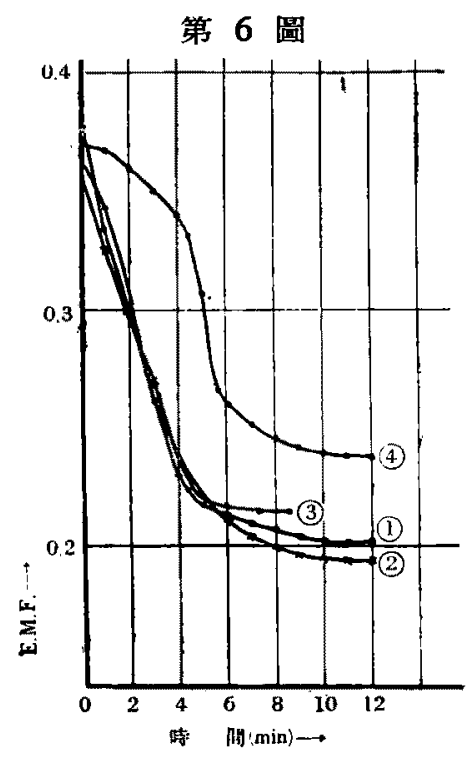

て少くとす約 $10 \mathrm{~min}$ 後には略、一定值に到達 するを見る。尤る(3)の場合には特に掜䢁を 急激に行つた，而して之等の溶液に芘性曹達 溶液を注意深く滴加すれば元の電仿迄複臨す るけれどす再び第6圆（4)の如く變化し初め 
3. 併し乍らこの (4)の場会の變化の様子は (1), (2), (3)门如人急激には變化してるない。

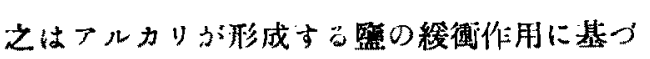

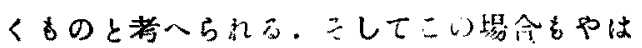
り電位办約 $10 \mathrm{~min}$ 後には略、一定值になる事 知る。体つて著者依滴定溶液上に窒素瓦斯

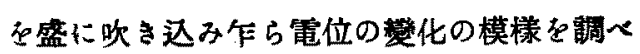
たる處全然上述の如き衒化証められなかつ た。毁ち電位の漸變が表れなかつた。故に之 見ても炭酸瓦斯に传り如何に滴定溶液か作

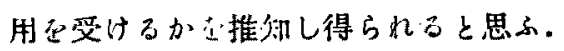

\section{III. 特殊銅に通用}

\section{（1）操 作 法}

前報に於て述心た如く特別の注意の下に中 和芷行つた試料溶液は蒸溜水々以て稀程し全

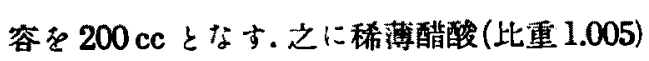
の約 $0.10 \mathrm{cc}$ 它滴加し約 $75^{\circ} \mathrm{C}$ の值溫慒中に移
し入れて湓度の一定方る待ち滴定に移る。

\section{(2)各璉の分析結果}

上記の如く操怍さ行つて種々の特殊鋼のタ ングステンを筫測した。るの結果を第 7 㘣站 び第 3 表に列筫したり。

第 7 娄 $\mathrm{Pb}\left(\mathrm{NO}_{3}\right)_{2} 1 \mathrm{cc}=0.00583 \mathrm{~g}(\mathrm{~W})$

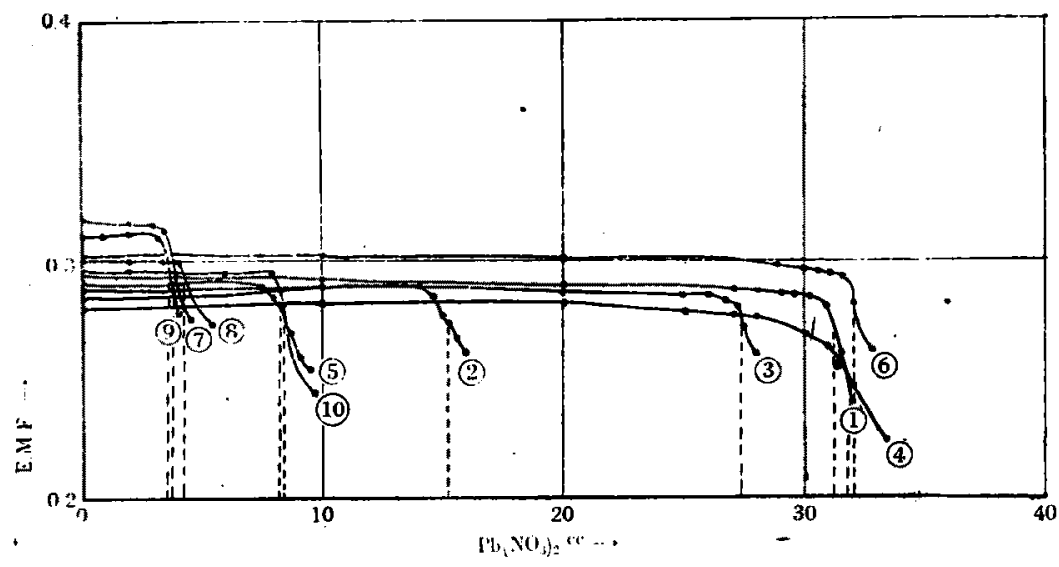

第 3 表

\begin{tabular}{|c|c|c|c|c|c|c|c|c|c|c|c|c|c|}
\hline 番號 & $\begin{array}{c}\text { 試料 } \\
\mathbf{g}\end{array}$ & $\begin{array}{c}\text { 所要 } \\
\mathbf{c c}\end{array}$ & $\begin{array}{c}\text { 本法 } \\
\text { 征 }\end{array}$ & \begin{tabular}{|c|} 
重量法 \\
$\%$
\end{tabular} & C & $\mathrm{Si}$ & $\mathbf{M n}$ & $\mathbf{P}$ & $\mathbf{S}$ & $\mathrm{Cu}$ & $\mathbf{N i}$ & $\mathbf{C r}$ & Mo \\
\hline (1) & 1 & 3.12 & 18.20 & 18.57 & 0.78 & 0.12 & 0.21 & 0.022 & 0.006 & 0.18 & 0.25 & 4.56 & 1.42 \\
\hline (2) & 1 & 15.52 & 9.10 & 9.34 & 1.00 & 0.16 & 0.16 & 0.020 & 0.005 & 0.14 & 0.28 & 2.26 & - \\
\hline (3) & I & 27.70 & 16.15 & 16.56 & 1.12 & 0.48 & 1.31 & 0.023 & 0.019 & 0.16 & 8.82 & 2.52 & 0.30 \\
\hline (4) & 1 & 31.80 & 18.54 & 18.69 & 0.74 & 0.30 & 0.20 & 0.020 & 0.010 & 0.15 & 0.28 & 0.28 & 2.23 \\
\hline (5) & 2 & 8.20 & 2.39 & 2.23 & 0.75 & 0.14 & 0.20 & 0.022 & 0.006 & 0.16 & 0.08 & 4.42 & 1.41 \\
\hline (B) & I & 3.80 & 18.66 & 18.64 & 0.70 & 0.26 & 0.21 & 0.018 & 0.006 & 0.19 & 0.15 & 4.69 & 1.24 \\
\hline (7) & 2 & 3.84 & 1.12 & 1.15 & 0.20 & 0.2 & 0.52 & 0.009 & 0.010 & 0.15 & 3.89 & 1.64 & 0.21 \\
\hline (8) & 2 & 4.30 & 1.25 & 1.21 & 0.20 & 0.15 & 0.50 & 0.012 & 0.010 & 0.20 & 3.83 & 1.59 & 0.18 \\
\hline (2) & 2 & 3.60 & 1.05 & 1.02 & 0.15 & 0.21 & 0.51 & 0.011 & 0.010 & 0.15 & 3.87 & 1.65 & 0.24 \\
\hline (10) & 2 & 8.30 & 2.42 & 2.50 & 0.43 & 2.12 & 0.37 & 0.012 & 0.004 & 0.11 & 13.67 & 14.95 & - \\
\hline
\end{tabular}


IV. 䊅 タングステンの電位差滴等行行ふに賞りタ ングステン酸曹達の試料溶液中に一定限量の 醋酸义は醌酸曹達孛添加して $75^{\circ} \mathrm{C}$ 前後に於 $\tau \frac{N}{20}$ 硝酸鉛規定液で滴定行行時は極めて

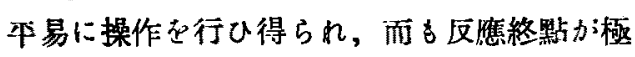

語

めて銳敏に表れ，從而佂確なる数值な得られ る事莡知りたり。

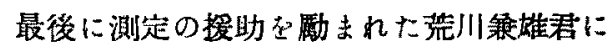
觖して謝意飞速ふ。（完） 